Grażyna Bąkowska-Czerner Krakow

\title{
A BONE DISC WITH AN INSCRIPTION FROM MARINA EL-ALAMEIN (EGYPT)
}

\begin{abstract}
A bone disc with an inscription has been found at the archaeological site of the Greco-Roman period at Marina el-Alamein in Egypt. It has a hole drilled in the center and a name IOULIOS (Iov́ $\lambda$ ios) written in Greek letters on one side. One may wonder about the disk function. Names appear on theatre tickets and on game counters, but they also usually bear a number or an image, e.g. a figure or a building. In the town, which has been subject of a recent research, a large number of diverse types of game pieces were discovered; glass pawns and bone counters predominate among them, however, they differ from the discussed disc: they are smooth or decorated with cut concentric circles. The number and variety of pawns indicates diverse types and a big popularity of games among the inhabitants of Marina. The described disc may have been a strategic board game counter.

Keywords: bone disc; game counter; Marina el-Alamein; Greco-Roman town

In the archaeological site of Marina el-Alamein (Matrouh Governorate, Egypt) (cf. Pl. 1: 1) in the Hellenistic-Roman period, there existed a small port town, of which much is already known (Daszewski 2011, 421-456; Bąkowska-Czerner and Czerner 2019, 19-39) (P1. 1: 2). Among numerous objects found there, there are some whose function is debatable. These include a bone disc with an inscription (P1. 2: 1-2). This object is $3.4 \mathrm{~cm}$ in diameter, $0.25 \mathrm{~cm}$ thick, with a hole in the middle of $0.35 \mathrm{~cm}$ in diameter. The surface is badly damaged, with cracks visible here and there, but certain traces indicate it was smoothed and polished. On one side above the opening,
\end{abstract}


there is an inscription in Greek letters: the Latin name (nomen) IOULIOS (Iov́ $\lambda_{10}$ ) - Greek version of IULIUS (A. Łajtar, personal communication, see Czerner et al. 2014, 74, Fig. 6c). It was cut crookedly and carelessly, the letters are of various sizes and shapes. The disc was found during the work of the Polish-Egyptian Conservation Mission in 2011, unfortunately, without context, on the surface west of the Roman baths (Czerner et al. 2014, 63-77). Therefore, its dating, as well as its function, is not clear.

These types of discoidal objects served different purposes: a counter (calculus) for a board game, a ticket or an appliqué inserted into various types of boxes or furniture. Since the disk had an opening in the middle, one may take into consideration that it might have served as a button or spindle-whorl (Rodziewicz 2007, 30). Many researchers identify similar items as tesserae (already Ovid used the term tessera to denote dice [Ov. Arts am. 3. 354]). They could have been used in theaters or amphitheaters as entry tickets for performances. In Athens, a tessera bearing the number thirteen and the inscription Aí $\chi \dot{\lambda} \lambda$ ov was found in the Odeon of Pericles; the digit would indicate the row, and the inscription the sector with the name derived sometimes, for example, from a statue standing in the theater (Bieber 1961, 24, see also Jentoft-Nilsen 1982, 159). Some of these types of tesserae were also treated as tokens with various functions in the economy and administration (Kokkinos 1992, 104-105). They were sometimes treated as 'free gifts' given by the emperor or officials that could be exchanged for money, and they also functioned as tickets or counters for games (Kokkinos 1992, 104). There are also examples that feature the image of the emperor with an inscription with his name or only the name of the ruler or another well-known person (Kokkinos 1992, 105-106).

Many archaeological sites and numerous collections contain characteristic discoid objects made from bone or sometimes ivory, once considered tickets but now regarded game counters by most researchers. Rostovtzew was the first to suggest such an interpretation (Rostovtzew 1905, 110-124). Typological analysis and iconographic studies were also conducted by E. Alföldi Rosenbaum (1984, 378-390). In the latest research, the function of these objects is also confirmed by E. Rodziewicz (2007, 30-32). Both the obverse and the reverse of these counters were usually decorated. The obverse would feature various images, which were sometimes signed on the reverse: heads or busts of men or women, figures associated with politics (for example Julius Caesar and representatives of the JulioClaudian dynasty) or with the world of culture and sports, characters from comedy (slaves, hetairai, sometimes as caricatures), as well as deities and 
theatrical masks. Images of landscapes, buildings and animals also occur (Bianchi 2015, 53). Roman numerals from I to XV would be visible on the reverse along with inscriptions usually identifying the representations on the obverse. The elements of decoration presented on these counters make researchers see a connection with Alexandrian art and culture (Bianchi 2015, 53). The images probably played a practical function, related to the rules of the game. It is believed that the main center of the production of game pieces was Alexandria, but they are also found outside Egypt, including Italy, Asia Minor, Greece, Syria, southern Russia and north of the Alps (Rostovtzew 1905, 123-124; Bianchi 2015, 56). This proves this game was popular in various regions of the empire. Based on portraits of the represented people, researchers are of the opinion that the counters were produced during the first domination of the Romans in Egypt (45 BC-68 AD), the last ruler that appears on them is Nero. Besides, the pieces of this type found in Kerch and studied by Rostovtzew were dated on the basis of ceramics from the 1st-2nd century AD (Rostovtzew 1905, 112-114, 121). It is not yet known exactly what type of game the counters were used for.

After more than 30 years of research at the site of Marina el-Alamein, we learn more and more about everyday life of the inhabitants of this ancient city. Games were definitely one of their pastimes. A relatively large number of both bone and glass game pieces, as well as glass marbles, were found in the houses. Most of the game pieces have a round base (diameter: $0.9-1.5 \mathrm{~cm}$, height: $0.5-0.8 \mathrm{~cm}$ ), and the upper surface is slightly convex (Kucharczyk 2005, 99, Fig. 3.11). They appear in black-greenish and cream shades. There are also disc-shaped glass counters as well as one taller pawn tapering upwards with a round base. The balls of various sizes (diameter: $1.2-2.1 \mathrm{~cm}$ ) are black-green, some were made of millefiori glass (Kucharczyk 2005, 99; Kucharczyk 2010, 126-127, Figs 8.5, 92). The marbles and game pieces were found in contexts dating back from the middle of the 1 st century to the 3rd century. Finds at the necropolis in Marina are also worth mentioning here. Gypsum mortar balls were discovered in several graves (Zych 2010, 337, 340, Fig. 5). They may have been put there so that the deceased could use them to play in the afterlife (for game pieces in funerary context, see Nuţu and Boţan 2009, 148-150). In Marina, there are also disc-shaped game pieces, which were made from used ceramic vessels and stones. Two of the three found bone game counters are discoid in shape and the third is conical. They are of various sizes (diameter: $1.6-2.5 \mathrm{~cm}$, height of about $0.2 \mathrm{~cm}$ ). All have a small hole in the middle, which is a trace of lathe machining. The conical counter has a smooth surface on both sides whereas the other 
two have decorations on the upper surface in the form of cut concentric circles around the central hole. The bone counters from Marina are dated to the 2nd-3rd century AD. They were definitely used for board games, which were very popular in Egypt, Greece, and Rome (Petrie 1927, 51-57).

Unfortunately, up until now, no game boards or holes in slabs which would help to identify the games played there have been found in the area of Marina. Glass pieces pawns were used in tabula lusoria (Solano 2015, 132-133), but the glass balls could have been used, for example, to play marbles (Schädler 1998, 10-25). A strategic board game known as ludus latrunculorum was a very common Roman pastime (Schädler 1994, 47-67), however, little is known about the rules of this game. Laus Pisonis contains its description with military terminology, and the game itself is compared to a battle (Laus Pis. 190-208, Schädler 2007, 363-364). We know from there the game was played with black and white pieces on a board. The goal was to surround and seize the other player's counters. The game is sometimes compared to the Greek petteia (pessoi) (Kurke 1999, 259-265; Richmond 1994, 177-179) and the Egyptian siga (seega) (Mulvin and Sidebotham 2004, 611-613; Schädler 2007, 364 ).

Games, popular with men as well as women and children, were an important element of everyday life in antiquity. They were enjoyed at home and in public spaces. The counters found in Marina indicate that different types of games were popular there as well.

However, the described disc from Marina differs from all the bone counters discussed above. One side bears an inscription while the other is smooth and has a hole in the middle. Chips with this type of hole do exist, sometimes decorated but more often smooth. The hole in the Marina counter was made intentionally, possibly to store it on a peg or hang on a string (Nuţu and Boţan 2009, 146). The hole drilled through the center could also have had some significance in the game itself. The inscription on the Marina disc is also wondering. It is what sets it apart from other bone counters that have been found. The cut out name must have signify something; maybe it was a figure in the game.

'Alexandrian' counters also bear the names of well-known people or emperors, identified by images shown on the obverse. Possibly the picture of this particular figure was not necessary as the inscribed name sufficed for the purposes of the game. There are examples of counters which only feature inscriptions, for instance, FELIX, a word thought to bring luck to the player, or $\mathrm{COH} / \mathrm{X}$, which might mean 10 cohorts in a strategy game (Mikler 1997, 30, 128, Tabl. 18, nos 17, 18). It is perfectly possible that 
the inscription on the disc from Marina referred to Julius Caesar and this token was also of tactical importance. Because it was found on the surface, it is difficult to date, but it was probably made during the 1 st and 2 nd centuries AD.

It is less likely that the disc served as a ticket for a show. In that case, the inscription would indicate the sector where its holder was supposed to sit. In Marina, no structure where performances could take place has been found so far, although the ticket could have been brought from another place, too, for example, from nearby Alexandria. Besides, if it served as a ticket, it wouldn't be a single find. Considering the characteristics of the Marina disc and comparing it with other artefacts, it seems that it was a board strategy game counter. Its uniqueness provokes further research, makes one wonder about different types of games popular in Marina and beyond.

\section{References}

Alföldi Rosenbaum E. 1984. Characters and Caricatures on Game Counters from Alexandria (Studies on Roman Game Counters 5). In N. Bonacasa, A. Di Vita (eds), Alessandria e il mondo ellenistico-romano. Studi in onore di Achille Adriani II. Rome, 378-390.

Bąkowska-Czerner G. and Czerner R. 2019. Marina el-Alamein, GrecoRoman town in Egypt. In G. Bąkowska-Czerner and R. Czerner (eds), Greco-Roman Cities at the Crossroads of Cultures: The 20th Anniversary of Polish-Egyptian Conservation Mission Marina el-Alamein, 19-39. (Archaeopress Archaeology). Oxford. https://doi.org/10.2307/j. ctvndv687.6.

Bianchi Ch. 2015. 'Pedine alessandrine': testimoni illustri di un gioco ignoto. In C. Lambrugo, F. Slavazzi, A. M. Fedeli (eds), I materiali della Collezione Archeologica "Giulio Sambon" di Milano. 1. Tra alea e agòn: giochi di abilità e di azzardo, 53-65. Florence.

Bieber M. 1961. History of the Greek and Roman Theatre. Princeton NJ.

Czerner R., Bąkowska-Czerner G., Grzegorek W. and Jasiewicz A. 2014. Marina el-Alamein Polish-Egyptian Conservation Mission: research and conservation in the 2011 season, PAM 23/1, 63-77. 
Daszewski W. A. 2011. Graeco-Roman town and necropolis in Marina elAlamein, PAM 20, 421-456.

Jentoft-Nilsen M. 1982. Some objects relating to the theatre, The J. Paul Getty Museum Journal 10, 159-164.

Kokkinos N. 1992. Antonia Augusta: Portrait of a Great Roman Lady. London, New York.

Kucharczyk R. 2005. Early roman glass from Marina el-Alamein, PAM 16, 93-99.

Kucharczyk R. 2010. Glass from houses 1 and 2 in Marina el-Alamein, PAM 19, 114-130.

Kurke L. 1999. Ancient Greek Board Games and How to Play Them, CPhil. 94, 1999, 247-267. https://doi.org/10.1086/449440.

Mikler H. 1997. Die römischen Fund aus Bein in Landesmuseum Mainz. Mainz.

Mulvin L. and Sidebotham S. E. 2004. Roman Game Boards from Abu Sha'ar (Red Sea Coast, Egypt), Antiquity 78, 602 -617. https://doi. org/10.1017/S0003598X00113250.

Nuţu G. and Boţan S. P. 2009. Roman board game pieces in Northern Dobrudja, Peuce, S.N. 7, 145-156.

Petrie F. W. M. 1927. Objects of Daily Use Illustrated by the Egyptian Collection in University College London. London.

Richmond J. 1994. The "Ludus Latrunculorum" and "Laus Pisonis" 190208. $M H$ 51/3, 164-179.

Rodziewicz E. 2007. Bone and Ivory Carvings from Alexandria. French Excavations 1992-2004, (Études alexandrines 12). Institut français d'archéologie orientale. Cairo.

Rostovtzew M. 1905. Interprétation des tessères en os avec figures, chiffres et légendes, Rev. Arch. 5, 110-124.

Schädler U. 1994. Latrunculi, ein verlorenes strategisches Brettspiel der Römer. In G. G. Bauer (ed.), Homo Ludens IV. Derspielende Mensch 4. Internationale Beiträge des Institutes für Spielforschung und Spielpädagogik an der Hochschule "Mozarteum" Salzburg, Munich, 47-67.

Schädler U. 1998. Mancala in Roman Asia Minor. Board Games Studies 1, 10-25.

Solano S. 2015. Una tabula lusoria e pedine da gioco dal santuario di Minerva a Breno (BS). In C. Lambrugo, F. Slavazzi, A. M. Fedeli (eds), Tra alea e agòn: giochi di abilità e di azzardo, Florence, 131-135. 
Zych I. 2010. Tomb T13 in the ancient Roman harbor town of Marina elAlamein - a special burial place. In J. Kościuk(ed.), Non solum villae. Ksiega jubileuszowa ofiarowana profesorowi Stanisławowi Medekszy, Wroclaw. 329-343.

Grażyna Bąkowska-Czerner Centre for Comparative Studies of Civilisations Jagiellonian University grazyna.bakowska-czerner@uj.edu.pl 


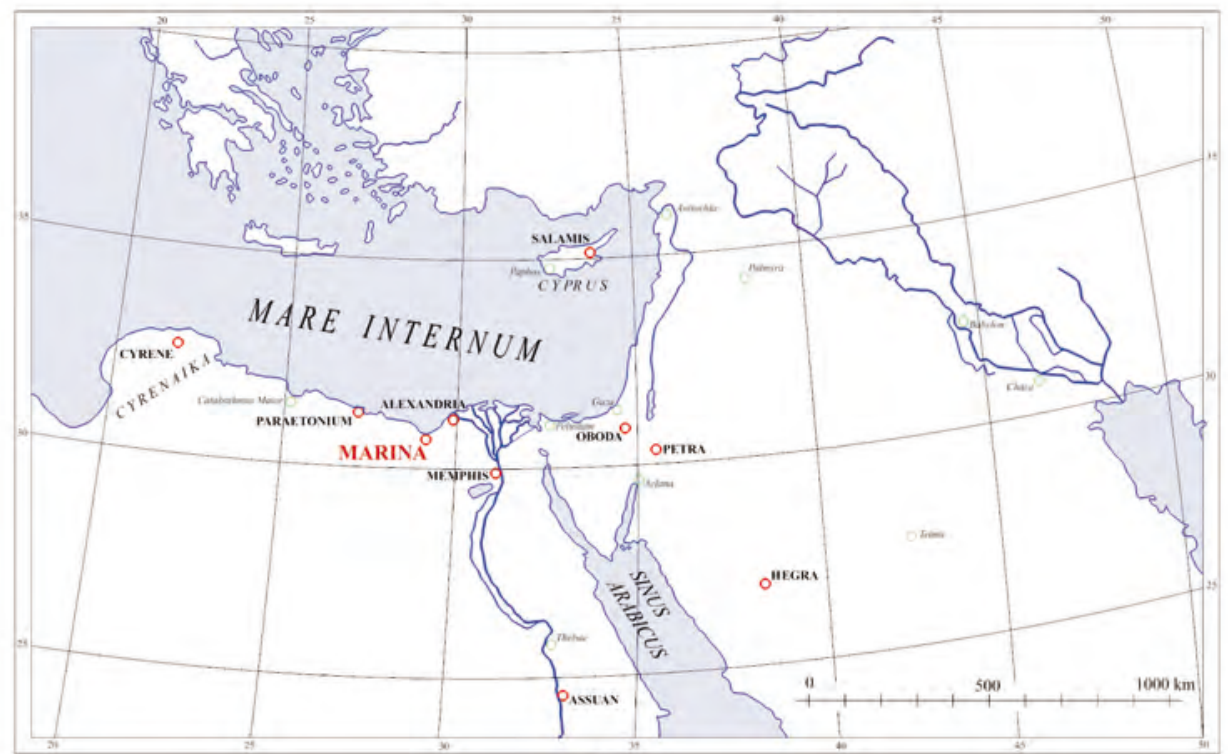

1

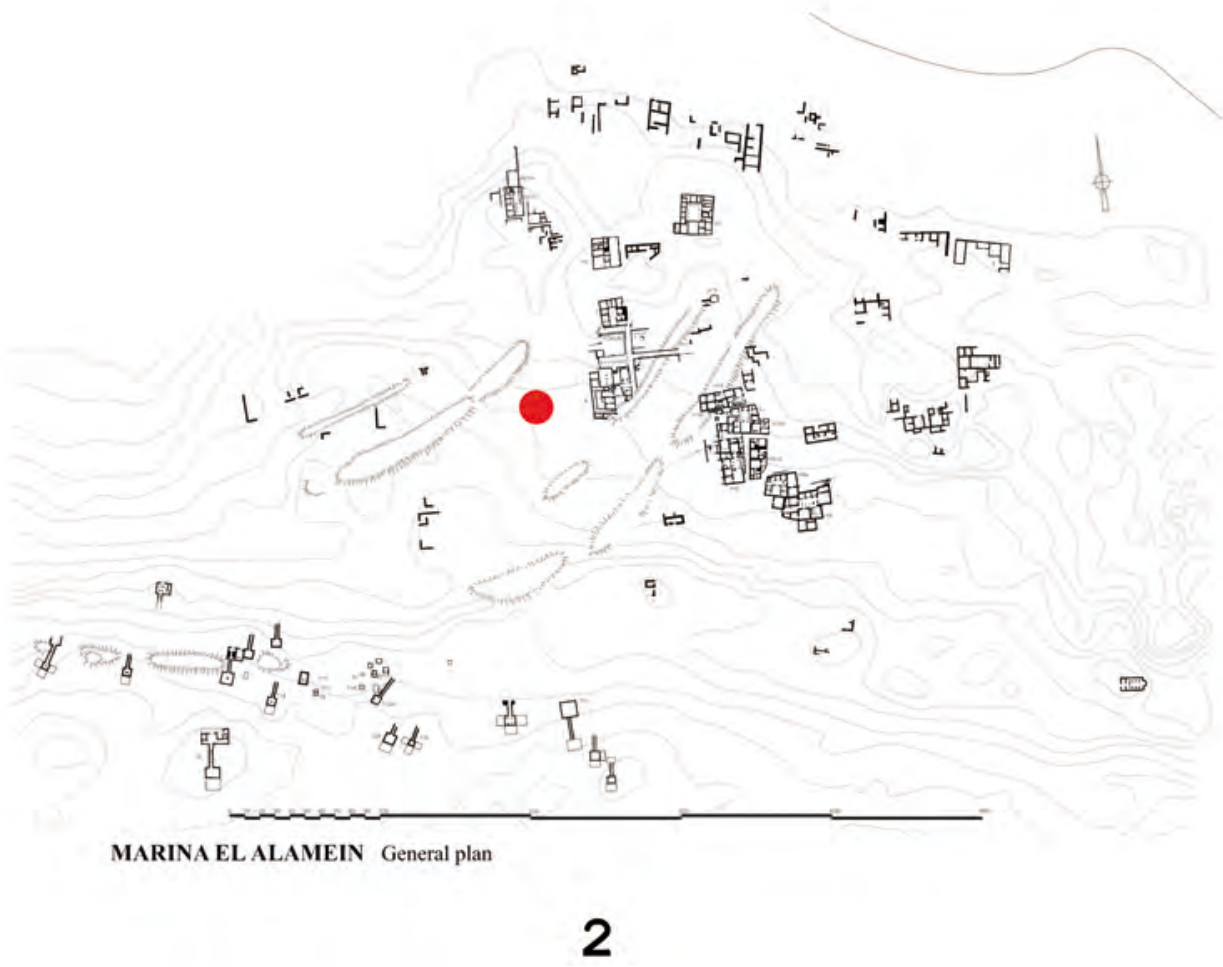

Pl. 1: 1. Location of Marina el-Alamein. Drawing R. Czerner

P1. 1: 2. Plan of the site. Findspot indicated by a dot. Drawing K. Majdzik, M.Krawczyk-Szczerbińska and R. Czerner 


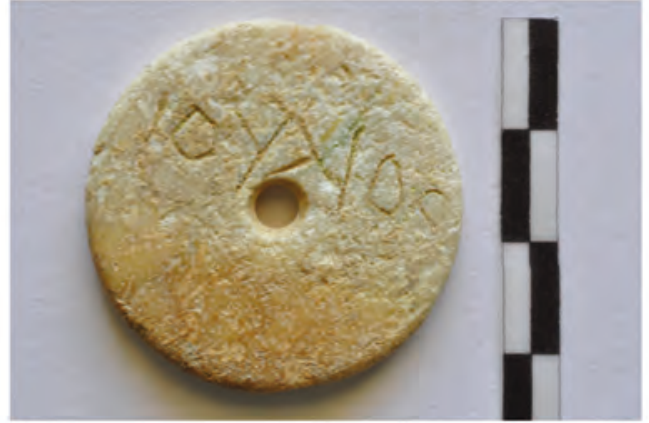

1

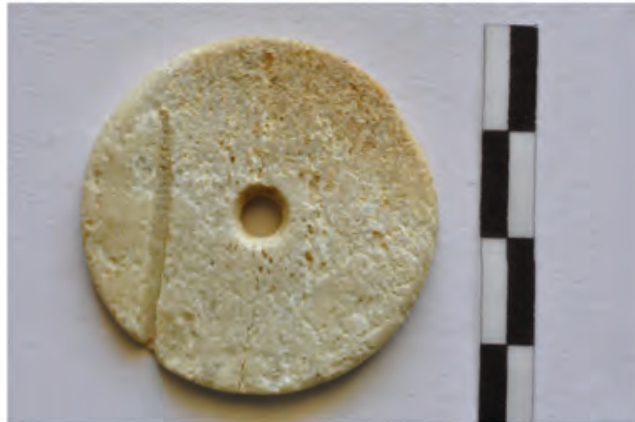

2
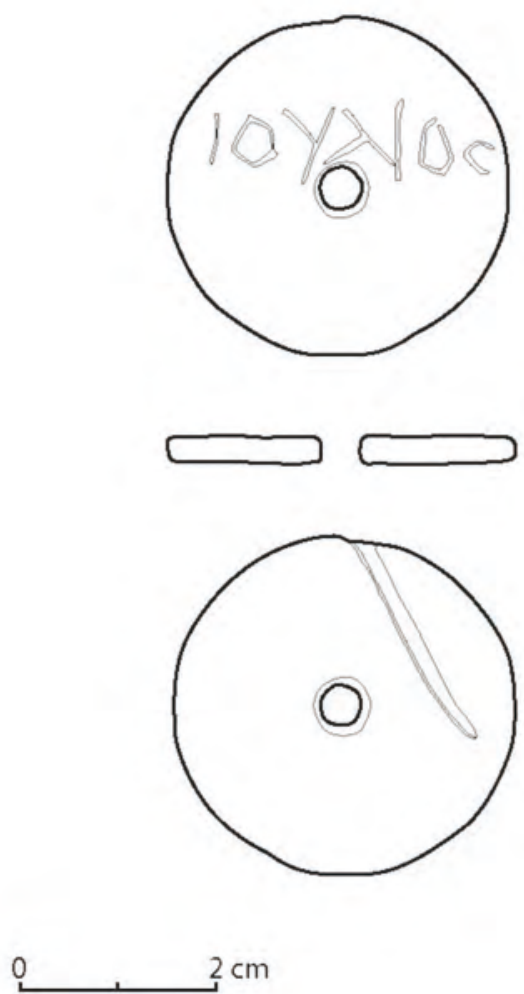

3

Pl. 2: 1-2 - Photo of the bone disc with an inscription discovered in Marina el-Alamein. Photo P. Zambrzycki

Pl. 2: 3 - Drawing of the bone disc with an inscription discovered in Marina el-Alamein. Drawing G. Bąkowska-Czerner, T. Witkowska 